\title{
Trend Analyses of Critical Values Obtained for Packets Per Distance Achievable in Ubicomp MANETs Using Location- Aware Transmission Strategies.
}

\author{
M. Kaleem GALAMALI, Assoc. Prof Nawaz MOHAMUDALLY
}

\begin{abstract}
The fields of location-tracking, ubicomp functionalities and MANET transmission strategies are subject to intense research [1-57]. Their merging is also subject to lots of attention. In particular, the enforcement of location-aware transmission strategies is prone to enhance energy management in ubicomp. Amongst the enhancements awaited [1] are: the application of landbased GPS systems, improved location refresh rates and accuracy, development of better protocols optimised for transmission according to distance criteria and refining the precision of the distance criteria to apply the protocol. The knowledge of distance coverages by transmitted packets in ubicomp and corresponding variations over different node densities, is definitely useful for refining transmission protocols in MANETs. Such an empirical study was made previously [26] whereby the metric Packets Per Distance, PPD, was devised and studied. This was followed by another study [42] in which the trends of parameters of equations for metric PPD were studied.
\end{abstract}

In this paper, the next level of scrutiny is set as: "What are the observable critical values in PPD trends? What are the trends of variation observable within each critical value for metric PPD over varying node densities?" Designers may use the results presented here, towards formulation of better "realistic" ubicomp scenarios for future ubicomp tools.

This piece of research remains a follow-up of previous ones [1-57].

Key terms: Ubicomp- Ubiquitous Computing, MAUCMobile and Ubiquitous Computing, PPD- Packets Per Distance, CBR- Constant Bit Rate, MANET- Mobile Adhoc Network, CV-Critical Value.

M. Kaleem GALAMALI,

University of Technology Mauritius (student) Mauritius

Assoc. Prof Nawaz Mohamudally University of Technology Mauritius, Mauritius

\section{Introduction}

Future ubicomp topographies, especially outdoor ones, may be deficiently equipped with networking devices. Different topographies may demonstrate quite a lot of heterogeneity concerning accuracy level of distance measurement, location refresh rates and performance level of existing protocols. MANETs remain the hopeful solution to these problems. Performance of MANETs may be enhanced with location-aware transmission. Various ways of studying the resulting Packet Per Distance coverages in ubicomp for most optimal protocol performances exist. One such method was introduced previously [26], in which the behaviour of the metric PPD was depicted as split into two:

- Previous to peak values, linear tendency is visible:

$$
F(x)=d * x+f
$$

- As from the peak value onwards, the exponentially trend is visible:

$$
G(x)=a * \exp (b *(x-c))
$$

A follow-up study [42] was carried out to model mathematically the five parameters of equations observed above. Results obtained will definitively be useful towards better understanding the evolution and predictability of ubicomp environments. These progresses are still laggardly occurring and will facilitate designers towards producing more realistic simulation scenarios based on which more precise test cases can be executed over experimental components for middleware and communication protocols.

The probing now required for metric PPD is the identification of observable critical values obtained during experiments execution and formulation of corresponding theoretical trend of such CVs over varying node densities. Nine such CVs were observed.

The key contribution of this paper is the mathematical derivation of the trends of variations for each of the nine CVs observed for metric PPD explained previously [26, 42] over node numbers ranging from 7 until 56. Such categories of information must necessarily be presented in a structured format so as to fluidly aid designers to understand the evolution and predictability of ubicomp behaviour and be well equipped to carry reliable simulation scenarios testing of new communication features. The rest of this paper is organised as follows: section 2- PPD Critical Values, section 3- Critical Values Trend Analyses- Metric PPD, section 4- Conclusion and References.

\section{PPD Critical Values.}

\section{$\underline{2.0 \text { Critical Values Identified. }}$}


Proc. of The Seventh Intl. Conf. On Advances In Computing, Control And Networking - ACCN 2017 Copyright (C) Institute of Research Engineers and Doctors, USA .All rights reserved.

ISBN: 978-1-63248-134-4 doi: 10.15224/ 978-1-63248-134-4-05

Nine CVs were identified as follows: Column headings are: $\mathrm{C} 1 \rightarrow \mathrm{PPD} \mathrm{CV}, \mathrm{C} 2 \rightarrow$ Meaning of PPD $\mathrm{CV}$, $\mathrm{C} 3 \rightarrow$ Corresponding figure number for PPD CV.

\begin{tabular}{|c|c|}
\hline C1 & C2 \\
\hline 1 Total number of packets in circulation. & 1 \\
$2 \%$ packets at 0 m. & 2 \\
\hline 3 Maximum distance packets travel. & 3 \\
$4 \%$ packets at maximum distance. & 4 \\
\hline 5 Modal value of distance packets travel. & 5 \\
$6 \%$ packets at modal value of distance. & 6 \\
\hline $7 \%$ packets travelling < modal value of distance. & 7 \\
\hline $8 \%$ packets travelling > modal value of distance. & 8 \\
\hline $9 \%$ packets at smallest value < modal value of & 9 \\
distance. &
\end{tabular}

\section{Table 1: PPD Critical Values}

It is recalled that distance is measured to nearest meter.

\subsection{Experimental Critical Values Obtained.}

The values obtained during experiments have been summarised below. Values have been rounded to a maximum of 9 decimal places. Column heading NN $\rightarrow$ Node Number.

\begin{tabular}{|c|c|c|c|}
\hline NN & CV1 & CV2 & CV3 \\
\hline 7 & 422948945 & 0.981875957 & 359 \\
\hline 8 & 487056531 & 14.310619110 & 359 \\
\hline 9 & 546986573 & 12.805610678 & 359 \\
\hline 10 & 629255705 & 11.594384353 & 363 \\
\hline 11 & 689282046 & 10.566200646 & 363 \\
\hline 12 & 748222616 & 9.774288753 & 363 \\
\hline 13 & 810253860 & 9.061030947 & 363 \\
\hline 14 & 871331869 & 8.446644800 & 363 \\
\hline 15 & 931865741 & 7.896057851 & 363 \\
\hline 16 & 990860926 & 7.413592067 & 363 \\
\hline 17 & 1051546908 & 7.006759227 & 363 \\
\hline 18 & 1110558045 & 6.630028149 & 363 \\
\hline 19 & 1172929399 & 6.293126003 & 363 \\
\hline 20 & 1231518084 & 5.984909029 & 363 \\
\hline 21 & 1290949156 & 5.690049113 & 369 \\
\hline 22 & 1348988525 & 5.441308183 & 369 \\
\hline 23 & 1408740211 & 5.211895453 & 389 \\
\hline 24 & 1468131004 & 5.001651678 & 389 \\
\hline 25 & 1529967229 & 4.788994928 & 389 \\
\hline 26 & 1589501936 & 4.506808100 & 381 \\
\hline 27 & 1649854293 & 4.351390866 & 381 \\
\hline 28 & 1711459977 & 4.205352329 & 388 \\
\hline 29 & 1771297512 & 4.070953327 & 388 \\
\hline 30 & 1829957752 & 3.942102593 & 389 \\
\hline 31 & 1886553606 & 3.815415728 & 389 \\
\hline 32 & 1944424833 & 3.702106699 & 389 \\
\hline 33 & 2005951676 & 3.599531826 & 389 \\
\hline 34 & 2066155746 & 3.500180668 & 389 \\
\hline 35 & 2125598932 & 3.404899669 & 389 \\
\hline 36 & 2188663557 & 3.317068664 & 389 \\
\hline 37 & 2246187164 & 3.191755796 & 389 \\
\hline 38 & 2303891929 & 3.104357592 & 389 \\
\hline 39 & 2365628914 & 3.026256129 & 389 \\
\hline & & & \\
\hline
\end{tabular}

\begin{tabular}{|c|c|c|c|c|}
\hline 40 & 2427171632 & 2.949503820 & 389 \\
\hline 41 & 2487197964 & 2.883629250 & 389 \\
\hline 42 & 2543796380 & 2.822532478 & 389 \\
\hline 43 & 2603692082 & 2.758803451 & 389 \\
\hline 44 & 2660028705 & 2.701091453 & 389 \\
\hline 45 & 2716735114 & 2.645611809 & 389 \\
\hline 46 & 2778428023 & 2.586327931 & 389 \\
\hline 47 & 2838831467 & 2.527322204 & 389 \\
\hline 48 & 2900907987 & 2.476683829 & 389 \\
\hline 49 & 2959346460 & 2.427038773 & 389 \\
\hline 50 & 3023618060 & 2.389524357 & 368 \\
\hline 51 & 3084282330 & 2.345783435 & 368 \\
\hline 52 & 3141277599 & 2.306740386 & 368 \\
\hline 53 & 3202570278 & 2.266356292 & 368 \\
\hline 54 & 3262306837 & 2.228893621 & 368 \\
\hline 55 & 3320546034 & 2.191417232 & 368 \\
\hline 56 & 3380459625 & 2.152764064 & 368 \\
\hline
\end{tabular}

Table 2(a): Experimental Critical Values Obtained(1)

\begin{tabular}{|c|c|c|c|}
\hline NN & CV4 & CV5 & CV6 \\
\hline 7 & 0.000225796 & 31 & 1.486884191 \\
\hline 8 & 0.000196076 & 31 & 1.287047725 \\
\hline 9 & 0.000174593 & 31 & 1.341119026 \\
\hline 10 & 0.001591563 & 32 & 1.358053162 \\
\hline 11 & 0.002944368 & 32 & 1.428853988 \\
\hline 12 & 0.002455152 & 29 & 1.500569184 \\
\hline 13 & 0.000821965 & 23 & 1.611943941 \\
\hline 14 & 0.001011096 & 23 & 1.686025787 \\
\hline 15 & 0.000632065 & 23 & 1.754024671 \\
\hline 16 & 0.001161111 & 23 & 1.820796494 \\
\hline 17 & 0.001008039 & 21 & 1.908077980 \\
\hline 18 & 0.001128262 & 21 & 1.980098933 \\
\hline 19 & 0.000861944 & 21 & 2.064416752 \\
\hline 20 & 0.000052780 & 21 & 2.122171273 \\
\hline 21 & 0.000002324 & 20 & 2.193066463 \\
\hline 22 & 0.000002224 & 19 & 2.252648517 \\
\hline 23 & 0.000262291 & 19 & 2.316725592 \\
\hline 24 & 0.000240442 & 19 & 2.366216973 \\
\hline 25 & 0.000235626 & 19 & 2.421309313 \\
\hline 26 & 0.000041208 & 19 & 2.475408246 \\
\hline 27 & 0.000027275 & 19 & 2.521171365 \\
\hline 28 & 0.000001636 & 19 & 2.560655557 \\
\hline 29 & 0.000001581 & 18 & 2.613029866 \\
\hline 30 & 0.000034154 & 18 & 2.654058048 \\
\hline 31 & 0.000128541 & 16 & 2.724988033 \\
\hline 32 & 0.000059915 & 16 & 2.762038320 \\
\hline 33 & 0.000062564 & 16 & 2.814523933 \\
\hline 34 & 0.000060741 & 16 & 2.860438286 \\
\hline 35 & 0.000012232 & 16 & 2.907832944 \\
\hline 36 & 0.000011194 & 16 & 2.963590671 \\
\hline 37 & 0.000031832 & 16 & 2.993781688 \\
\hline 38 & 0.000044707 & 16 & 3.036857681 \\
\hline 39 & 0.000041004 & 16 & 3.071178813 \\
\hline 40 & 0.000036256 & 16 & 3.108190043 \\
\hline 41 & 0.000023923 & 16 & 3.142586201 \\
\hline 42 & 0.000054485 & 16 & 3.178529643 \\
\hline 43 & 0.000019011 & 16 & 3.223753284 \\
\hline 44 & 0.000015413 & 16 & 3.271821159 \\
\hline 45 & 0.000030183 & 16 & 3.297024084 \\
\hline & & & \\
\hline 10.0
\end{tabular}


Proc. of The Seventh Intl. Conf. On Advances In Computing, Control And Networking - ACCN 2017 Copyright (C) Institute of Research Engineers and Doctors, USA .All rights reserved.

ISBN: 978-1-63248-134-4 doi: 10.15224/ 978-1-63248-134-4-05

\begin{tabular}{|c|c|c|c|}
\hline 46 & 0.000022387 & 14 & 3.323815778 \\
\hline 47 & 0.000021910 & 14 & 3.364481165 \\
\hline 48 & 0.000039367 & 14 & 3.402162545 \\
\hline 49 & 0.000047139 & 14 & 3.433064779 \\
\hline 50 & 0.000041507 & 14 & 3.495962053 \\
\hline 51 & 0.000044095 & 14 & 3.531660411 \\
\hline 52 & 0.000043454 & 13 & 3.563593044 \\
\hline 53 & 0.000038563 & 13 & 3.601462450 \\
\hline 54 & 0.000030806 & 13 & 3.636982967 \\
\hline 55 & 0.000029965 & 13 & 3.672141833 \\
\hline 56 & 0.000032096 & 13 & 3.708147794 \\
\hline
\end{tabular}

Table 2(b): Experimental Critical Values Obtained(2)

\begin{tabular}{|r|l|l|l|l|}
\hline NN & CV7 & CV8 & CV9 \\
\hline 7 & 24.939505405 & 73.573610403 & 0.103547723 \\
\hline 8 & 35.044535518 & 63.668416757 & 0.089743997 \\
\hline 9 & 36.092018295 & 62.566862679 & 0.091348495 \\
\hline 10 & 41.204701036 & 57.437245801 & 0.394979335 \\
\hline 11 & 42.590221043 & 55.980924970 & 0.400278089 \\
\hline 12 & 39.503209831 & 58.996220986 & 0.395673017 \\
\hline 13 & 31.767608858 & 66.620447202 & 0.424520779 \\
\hline 14 & 32.552183398 & 65.761790815 & 0.425772445 \\
\hline 15 & 33.432083217 & 64.813892112 & 0.417240256 \\
\hline 16 & 34.299571825 & 63.879631681 & 0.404137543 \\
\hline 17 & 31.484008605 & 66.607913415 & 0.393326343 \\
\hline 18 & 32.343153212 & 65.676747855 & 0.390380586 \\
\hline 19 & 33.213462237 & 64.722121011 & 0.386610055 \\
\hline 20 & 34.124319526 & 63.753509201 & 0.386494040 \\
\hline 21 & 33.030815584 & 64.776117953 & 0.386774954 \\
\hline 22 & 31.567489501 & 66.179861982 & 0.386142425 \\
\hline 23 & 32.229636128 & 65.453638279 & 0.385123102 \\
\hline 24 & 32.977795965 & 64.655987062 & 0.387162044 \\
\hline 25 & 33.583386968 & 63.995303719 & 0.387384899 \\
\hline 26 & 34.433058596 & 63.091533158 & 0.388714028 \\
\hline 27 & 35.062366807 & 62.416461828 & 0.390629708 \\
\hline 28 & 35.692767006 & 61.746577437 & 0.391423176 \\
\hline 29 & 33.765588782 & 63.621381353 & 0.396489238 \\
\hline 30 & 34.366073605 & 62.979868346 & 0.397100916 \\
\hline 31 & 29.698780529 & 67.576231438 & 0.393249149 \\
\hline 32 & 30.174391781 & 67.063569898 & 0.398176616 \\
\hline 33 & 30.773853597 & 66.411622470 & 0.402132220 \\
\hline 34 & 31.291341723 & 65.848219992 & 0.406607489 \\
\hline 35 & 31.871070398 & 65.221096658 & 0.412663785 \\
\hline 36 & 32.440252351 & 64.596156978 & 0.416755694 \\
\hline 37 & 33.027181345 & 63.979036967 & 0.422846731 \\
\hline 38 & 33.621601571 & 63.341540748 & 0.428413671 \\
\hline 39 & 34.228084008 & 62.700737179 & 0.438074372 \\
\hline 40 & 34.873003534 & 62.018806423 & 0.443854767 \\
\hline 41 & 35.392554101 & 61.464859699 & 0.450651664 \\
\hline 42 & 35.869842027 & 60.951628330 & 0.456348161 \\
\hline 43 & 36.542150993 & 60.234095723 & 0.462840022 \\
\hline 44 & 37.023658397 & 59.704520444 & 0.467972055 \\
\hline 45 & 37.461802395 & 59.241173521 & 0.471052512 \\
\hline 46 & 31.333338629 & 65.342845594 & 0.476229540 \\
\hline 47 & 31.817519656 & 64.817999180 & 0.483648331 \\
\hline 48 & 33.227219105 & 64.370618350 & 0.489521800 \\
\hline 49 & 32.616508342 & 63.950426879 & 0.495629363 \\
\hline 50 & 33.205882922 & 63.298155026 & 0.509864430 \\
\hline 51 & 33.590305009 & 62.878034580 & 0.513783866 \\
\hline & & & \\
\hline
\end{tabular}

\begin{tabular}{|l|l|l|l|l|}
\hline 52 & 30.423828518 & 66.012578438 & 0.521119496 \\
\hline 53 & 30.841224993 & 65.557312557 & 0.528190938 \\
\hline 54 & 31.183804738 & 65.179212295 & 0.534227553 \\
\hline 55 & 31.542650946 & 64.785207221 & 0.541115462 \\
\hline 56 & 31.951312922 & 64.340539284 & 0.551490687 \\
\hline
\end{tabular}

Table 2(c): Experimental Critical Values Obtained(3)

\section{Critical Values Trend Analyses- Metric PPD.}

\subsection{General Procedure Adopted.}

The initial logical step is to plot the tabulated data for each PPD CV on gnuplot. The step that must follow is the graphical analyses and relating the general observations obtainable. As third step, different equations of fits are experimented. Choice of best fit is made based values of least reduced chi-square and best extendability produced at node numbers 80, 100 and 120 for eight CVs; and for one CV, it is based on flat values. The conclusive step is documenting the related parameter values for each PPD CV equation.

\subsection{Trend Analysis - PPD CV1.}

The number of packets in circulation tends to increase very linearly with number of nodes.

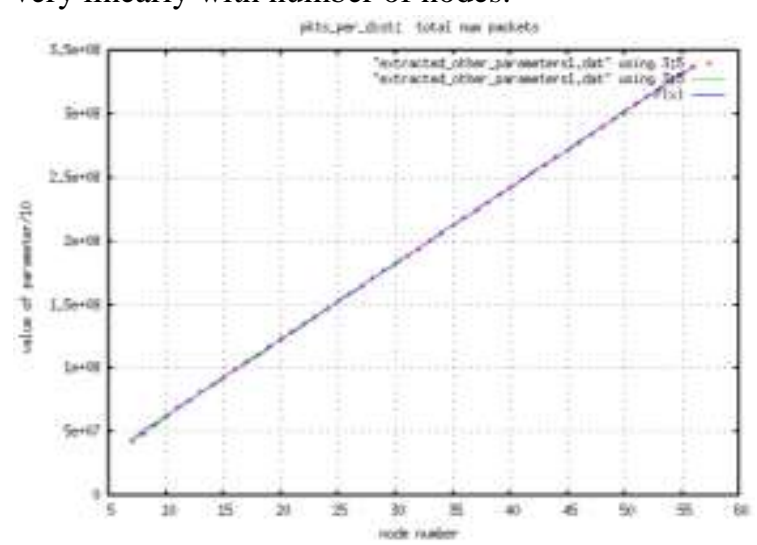

Figure 1: PPD Critical Value 1

The applicable equation of trend has been

$\mathrm{F}(\mathrm{x})=(\mathrm{d} \star \mathrm{x}+\mathrm{f}) * 10$

Ch_sq $=4.19638\left(\mathrm{e}^{11}\right) \quad \mathrm{F}(80)=4821197343.51367$

$\mathrm{F}(100)=6019565585.97704 \quad \mathrm{~F}(120)=7217933828.44041$

The parameters obtained for best fit are: $\quad d=5.991$ $84\left(\mathrm{e}^{+06}\right), \mathrm{f}=2.77244\left(\mathrm{e}^{+06}\right)$

Ch_sq is not 0 despite appearance of very clean linear tendency. This is because the y-values on the y-axis are very large and have a large range. The vertical distance from plots to the line are very well existent but are not visible on graphical display.

\subsection{Trend Analysis - PPD CV2.}

The first plot at node number 7 appears as an outlier: it is hence ignored for fitting equation. Else, the plots show a decreasing trend at a decreasing rate. 


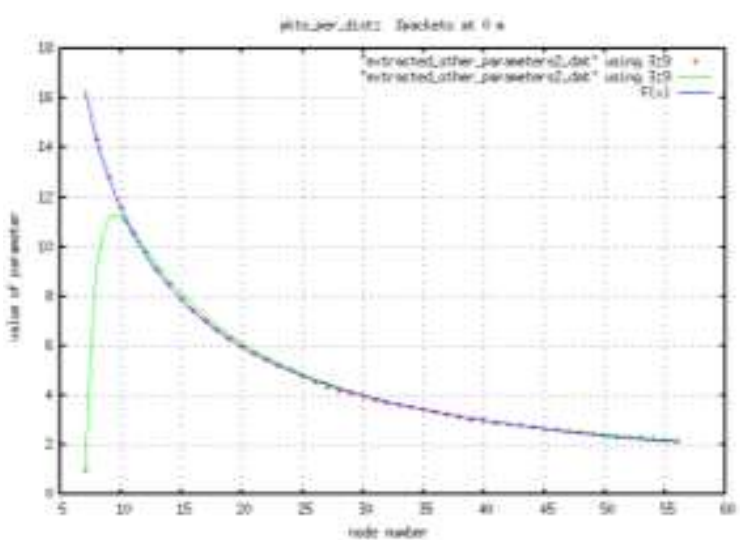

Figure 2: PPD Critical Value 2

The potentially applicable equations are:

1. $F(x)=\exp \left(\left(b * x^{-0.5}\right)+c\right)+d$

Ch_sq $=0.00355662 \quad \mathrm{~F}(80)=1.284692863$

$\mathrm{F}(100)=0.893812946 \quad \mathrm{~F}(120)=0.615902522$

2. $F(x)=\exp \left(\left(b * x^{a}\right)+c\right)+d$

$$
\text { Ch_sq }=0.00146368 \quad \mathrm{~F}(80)=1.410337958
$$

$\mathrm{F}(100)=1.081443152 \quad \mathrm{~F}(120)=0.857716052$

Choice of best fit for PPD Critical Value 2

The equation in part 2 above has been selected because of smallest reduced chi-square value obtained and good extendability. The parameters for best fit are:

$a=-0.0190953, b=50.4263, c=-45.77, d=-0.427347$

\subsection{Trend Analysis - PPD CV3.}

Instead of a consistent curve of tendency, four distinct levels of max_distance_packets travel are noted:

\begin{tabular}{|c|c|c|}
\hline Level & Node & Y-axis \\
\hline 1 & $7-9$ & 359 \\
\hline 2 & $10-22$ & 363 \\
\hline 3 & $23-49$ & 389 \\
\hline 4 & $50-56$ & 368 \\
\hline
\end{tabular}

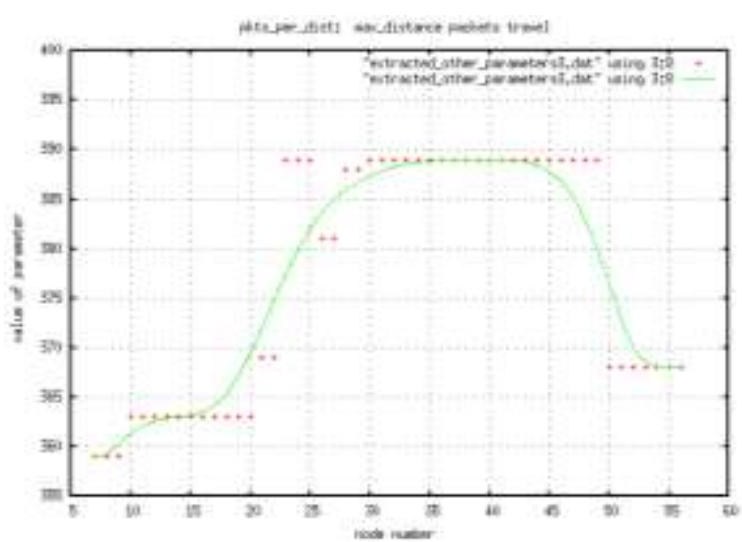

Figure 3: PPD Critical Value 3

Range of node numbers for levels 1 until 3 depict an increasing value. It can be suggested that level 4 will hold for node number around 50-90.

\subsection{Trend Analysis - PPD CV4.}

Here, certain initial sudden upward bursts are noted but the plots are mostly stabilising at very low values.

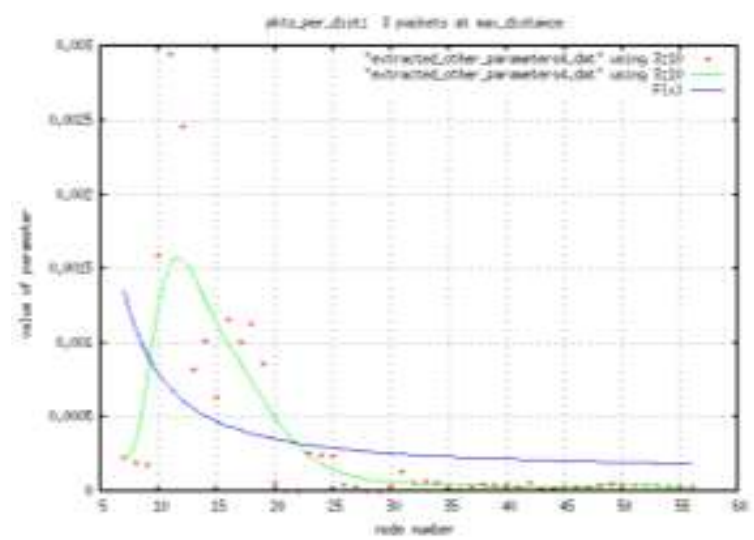

Figure 4: PPD Critical Value 4

The potentially applicable equations are:

$$
\begin{aligned}
& 1 \cdot F(x)=(a / \log (x))+b \\
& \text { Ch_sq }=2.65504\left(\mathrm{e}^{-07}\right) \quad \mathrm{F}(80)=-0.000138193 \\
& F(100)=-0.000198911 \quad F(120)=-0.000244319 \\
& \text { 2. } F(x)=(a / \log (x))+(b / x) \\
& \text { Ch_sq }=2.76297\left(\mathrm{e}^{-07}\right) \quad \mathrm{F}(80)=-8.95 \text {. } \\
& \mathrm{F}(100)=-3 \ldots \ldots \ldots \ldots . \quad \mathrm{F}(120)=-4.85 \ldots \ldots \ldots \\
& 3 \cdot F(x)=(a / \log (x))+\left(b / x^{2}\right) \\
& \text { Ch_sq }=3.1568\left(\mathrm{e}^{-07}\right) \quad \mathrm{F}(80)=0.000163944 \\
& \mathrm{~F}(100)=0.000153617 \quad \mathrm{~F}(120)=0.000146457 \\
& \text { 4. } F(x)=(a / \log (x))+\left(b / x^{c}\right) \\
& \text { Ch_sq }=2.30792\left(\mathrm{e}^{-07}\right) \quad \mathrm{F}(80)=-0.000559 \\
& \mathrm{~F}(100)=-0.000733348 \quad \mathrm{~F}(120)=-0.000866367
\end{aligned}
$$

\section{Choice of best fit for PPD Critical Value 4}

The equation in part 3 above has been selected because of good extendability over larger node numbers even if ch_sq is not least. The parameters obtained for best fit are: $\quad a=0.000684885, b=0.0489652$

\subsection{Trend Analysis - PPD CV5.}

Here, some staircase features are noted but overall is a decreasing curve at a decreasing rate.

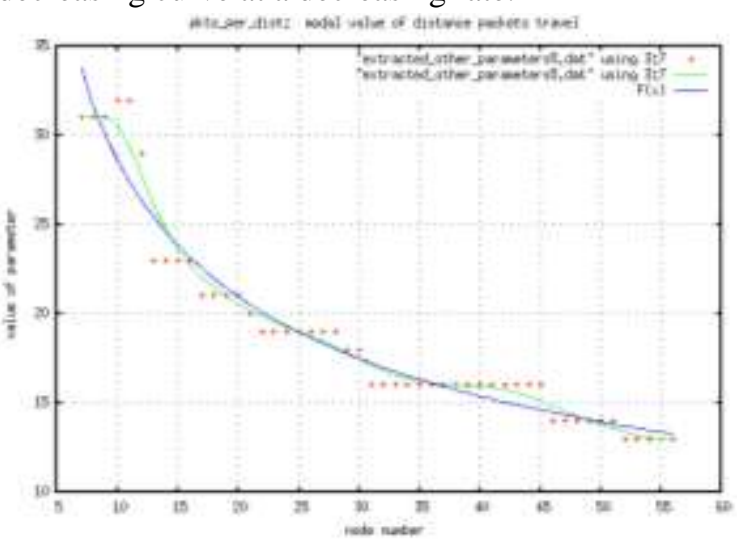

Figure 5: PPD Critical Value 5

The potentially applicable equations are:

$$
\begin{array}{rl}
\text { 1. } F(x)=\exp \left(\left(b \star x^{a}\right)+c\right)+d \\
\text { Ch_sq }=1.65649 \quad F(80)=11.307736257 \\
F(100)=10.252269005 & F(120)=9.466508066 \\
\text { 2. } F(x)=\left(f * x^{2}\right) \star \exp \quad\left(\left(b * x^{a}\right)+c\right)+d
\end{array}
$$


Proc. of The Seventh Intl. Conf. On Advances In Computing, Control And Networking - ACCN 2017 Copyright (C) Institute of Research Engineers and Doctors, USA .All rights reserved.

ISBN: 978-1-63248-134-4 doi: 10.15224/ 978-1-63248-134-4-05

$$
\begin{array}{lc}
\text { Ch_sq }=1.71179 & F(80)=11.704860354 \\
F(100)=10.810789776 & F(120)=10.170303629 \\
\text { 3. } F(x)=\left(f * x^{-1}\right) * \exp \left(\left(b * x^{a}\right)+c\right)+d \\
\text { Ch_sq }=1.69348 & F(80)=11.326135786 \\
F(100)=10.276584195 & F(120)=9.495603665 \\
\text { 4. } F(x)=\left(f * x^{-2}\right) & \star \exp \left(\left(b * x^{a}\right)+c\right)+d \\
\text { Ch_sq }=1.69834 & F(80)=11.384389394 \\
F(100)=10.349407290 & F(120)=9.579216930
\end{array}
$$

\section{Choice of best fit for PPD Critical Value 5}

The equation in part 3 above has been selected because of good extendability over larger node numbers even if ch_sq is not least. The parameters obtained for best fit are: $\quad \mathrm{a}=0.0105585, \mathrm{~b}=49.8461, \mathrm{c}=-46.5017$, $\mathrm{d}=0.296785, \mathrm{f}=2.93822$

\subsection{Trend Analysis - PPD CV6.}

The curve obtained here is generally increasing at a decreasing rate.

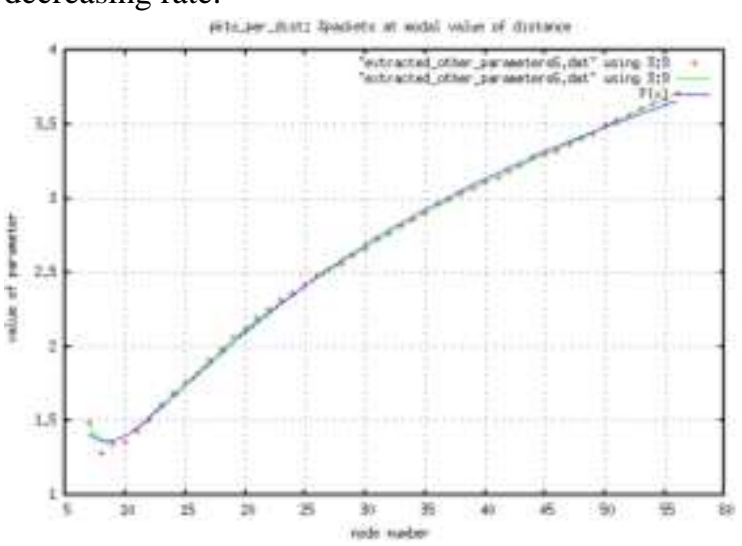

Figure 6: PPD Critical Value 6

The potentially applicable equations are:

$$
\begin{aligned}
& \text { 1. } F(x)=\left(a / x^{0.5}\right) \star \log (b *(x-c))+d \\
& \text { Ch_sq }=0.000856076 \quad \mathrm{~F}(80)=4.196112369 \\
& \mathrm{~F}(100)=4.521891051 \quad \mathrm{~F}(120)=4.779101964 \\
& 2 \cdot F(x)=\left(a * x^{f}\right) * \log (b *(x-c))+d \\
& \text { Ch_sq }=0.00208645 \quad \mathrm{~F}(80)=4.414093057 \\
& \mathrm{~F}(100)=4.890246564 \quad \mathrm{~F}(120)=5.298307187
\end{aligned}
$$

\section{Choice of best fit for PPD Critical Value 6}

The equation in part 1 above has been selected because of least ch_sq and good extendability over larger node numbers. The parameters obtained for best fit are:

$a=-8.93294, b=1.93451, c=1.79934, d=9.20889$

\subsection{Trend Analysis - PPD CV7.}

The plots are quite scattered. Different straight line trends are visible for different ranges. Overall, the decreasing linear trend applies best with possibility of tolerance limit of \pm 4 .

The applicable equation is: $F(x)=d * x+f$

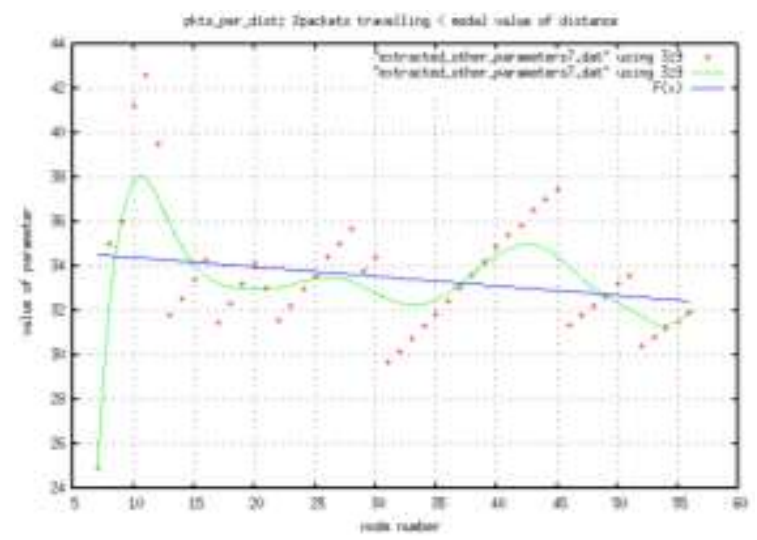

Figure 7: PPD Critical Value 7

Ch_sq $=8.24483 \quad \mathrm{~F}(80)=31.424242282$

$\mathrm{F}(100)=30.573845488 \quad \mathrm{~F}(120)=29.723448693$

Parameters for best fit: $\mathrm{d}=-0.0425198, \mathrm{f}=34.8258$

\subsection{Trend Analysis - PPD CV8.}

Nearly same observations as in critical value 7 are made here also. A very mildly decreasing linear tendency seems to apply with tolerance limits.

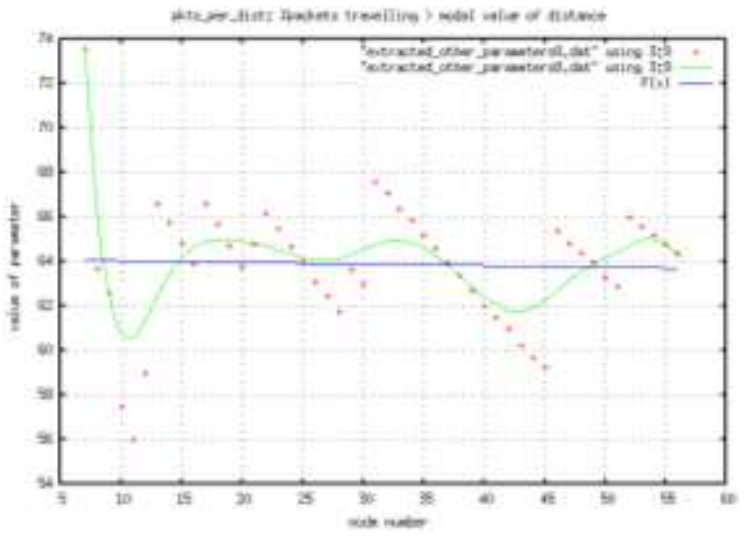

Figure 8: PPD Critical Value 8

The applicable equation is: $\mathrm{F}(\mathrm{x})=\mathrm{d} \star \mathrm{x}+\mathrm{f}$

$$
\begin{array}{ll}
\text { Ch_sq }=8.05268 & F(80)=63.526228566 \\
F(100)=63.381479176 & F(120)=63.236729786
\end{array}
$$

Parameters for best fit: $d=-0.00723747, f=64.1052$ A tolerance limit of \pm 3.5 is suggested here.

\subsection{Trend Analysis - PPD CV9.}

The curve obtained here depicts rapid initial increase reaching a peak, then decreases reaching a minimum point and continues increasing at a moderately increasing rate.

The potentially applicable equations are:

$$
\begin{aligned}
& \text { 1. } F(x)=h /\left(\left(a^{*}(x-g)^{2}\right)+b\right) /\left(\exp \left(\left(c^{*}(x-g)\right)+d\right)+f\right) \\
& \text { Ch_sq }=0.00109905 \quad \mathrm{~F}(80)=1.179379672 \\
& \mathrm{~F}(100)=2.472680445 \quad \mathrm{~F}(120)=5.646313040 \\
& \text { 2. } F(x)=h /\left(\left(a^{\star}(x-g)^{2}\right)+b\right) /\left(\operatorname { e x p } \left(\left(c^{*}(x-\right.\right.\right. \\
& \text { g) })+d)+(f / x)) \\
& \text { Ch_sq }=0.00124297 \quad \mathrm{~F}(80)=1.173660133 \\
& \mathrm{~F}(100)=2.452859198 \quad \mathrm{~F}(120)=5.561602609
\end{aligned}
$$

3. $F(x)=h /\left(\left(a^{*}(x-g)^{2}\right)+b\right) /\left(\exp \quad\left(\left(c^{*}(x-\right.\right.\right.$ $\left.g))+d)+\left(f / x^{2}\right)\right)$ 


\section{Ch_sq $=0.00128457 \quad \mathrm{~F}(80)=1.146142641$ \\ $\mathrm{F}(100)=2.346248710 \quad \mathrm{~F}(120)=5.200410920$}

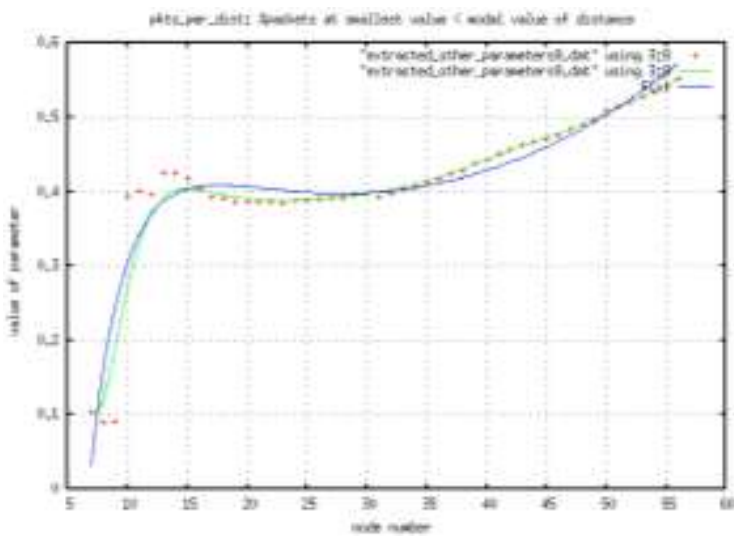

Figure 9: PPD Critical Value 9

Choice of best fit for PPD Critical Value 9

The equation in part 3 above has been selected even if the reduced ch_sq is not smallest, it has good extendability over larger node numbers. The parameters obtained for best fit are:

$\mathrm{a}=0.380727, \mathrm{~b}=69.1525, \mathrm{c}=0.0580143, \mathrm{~d}=-$

$0.22762, f=-49.8016, g=1.61181, h=36.7189$

\section{Conclusion.}

This study had as aim the determination of the relevant CVs observable for metric PPD and analyse their corresponding trends over varying node densities in a MANET topography of $300 \times 300 \mathrm{~m}^{2}$. The models portrayed in this paper, are framed with mathematical equations of quite complex levels. The output detailed here will add to the amount of existing tools for more detailed MANETs studies for ubicomp environments viewed from software engineering notions. These output can subtly be implemented into computational methods to develop better simulation scenarios which will then serve for enabling better testing procedures over communication and middleware components.

This experiment was performed in NS-2 over Linux. Plottings and "Fit" attempts were done with gnuplot software. Determination of best fit was done using least reduced chi-square and best extendability at higher node numbers for eight CVs and flat value for one CV. Assumptions stated previously [26, 42] are maintained.

This study is positioned as a follow-up to previous studies [1-57]. Upgrades to these results remain possible in the future. One such task is the formulation of predictability for metric PPD and its trend.

\section{References}

[1] M. Kaleem GALAMALI, Assoc. Prof Nawaz MOHAMUDALLY, Towards Dependable Pervasive Systems-A Position and Vision Paper, CEET 2014

[2] M. Kaleem GALAMALI, Assoc Prof Nawaz
MOHAMUDALLY, Model of Energy Savings achievable with Location-aware Node-to-Node Transmission in UbiComp, CEET 2014

[3] M. Kaleem GALAMALI, Assoc. Prof Nawaz MOHAMUDALLY, Model of Energy Savings achievable with Location-aware Node-to-Node Transmission in UbiComp Using Location Refresh Intervals, CEET 2014

[4] M. Kaleem GALAMALI, Assoc. Prof Nawaz MOHAMUDALLY, Model of Energy Savings achievable with Location-aware Transmission in UbiComp Using Relays, CEET 2014

[5] M. Kaleem GALAMALI, Assoc. Prof Nawaz MOHAMUDALLY, Mathematical modeling of need of exact number of relays to ensure seamless mobility in mobile computing, CEET 2014

[6] M. Kaleem GALAMALI, Assoc. Prof Nawaz MOHAMUDALLY, Modelling of need for multiple relays for ensuring seamless mobility, CEET 2014

[7] M. Kaleem GALAMALI, Assoc. Prof Nawaz MOHAMUDALLY, Investigation of prominence of placements of relays in a ubicomp topography,

[8] M. Kaleem GALAMALI, Assoc. Prof Nawaz MOHAMUDALLY, Model of energy savings achievable with location-aware transmission in ubicomp using optimised number of relays.

[9] M. Kaleem GALAMALI, Assoc. Prof Nawaz MOHAMUDALLY, Investigation of Prominence of Placements of Optimised Number of Relays in a Ubicomp Topography using Location-Aware Transmission, CEET 2015.

[10] M. Kaleem GALAMALI, Assoc. Prof Nawaz MOHAMUDALLY, Extending Node Battery Availability in Ubicomp with Location-Aware Transmission, CEET 2015.

[11] M. Kaleem GALAMALI, Assoc. Prof Nawaz MOHAMUDALLY, Extending Node Battery Availability in Ubicomp with Location-Aware Transmission using Location Refresh Intervals, CEET 2015

[12] M. Kaleem GALAMALI, Assoc. Prof Nawaz MOHAMUDALLY, Extending Node Battery Availability in Ubicomp with Location-Aware Transmission using Uniformly Placed Relays, CEET 2015.

[13] M. Kaleem GALAMALI, Assoc. Prof Nawaz MOHAMUDALLY, Extending Node Battery Availability in Ubicomp with Location-Aware Transmission Using Optimally Placed Relays, CEET 2015.

[14] M. Kaleem GALAMALI, Assoc. Prof Nawaz MOHAMUDALLY, Model of Sender Node Energy Savings Achievable with Location-Aware MANET Transmission in Ubicomp. ACCN 2016

[15] M. Kaleem GALAMALI, Assoc. Prof Nawaz MOHAMUDALLY, Model of Overall Node Energy Savings Achievable with Location-Aware MANET Transmission in Ubicomp. ACCN 2016

[16] M. Kaleem GALAMALI, Assoc. Prof Nawaz MOHAMUDALLY, Model of Sender Node Extra Energy Savings Achievable in MANET Against Direct Node-toNode Transmission Using Location-Aware Transmission in Ubicomp. ACCN 2016

[17] M. Kaleem GALAMALI, Assoc. Prof Nawaz MOHAMUDALLY, Model of Overall Node Extra Energy Savings Achievable in MANET against Direct Node-toNode Transmission Using Location-Aware Transmission in Ubicomp. ACCN 2016

[18] M. Kaleem GALAMALI, Assoc. Prof Nawaz MOHAMUDALLY, Model of Energy Consumption Ratio Achievable in MANET Using Location-Aware Transmission in Ubicomp. ACCN 2016

[19] M. Kaleem GALAMALI, Assoc. Prof Nawaz MOHAMUDALLY, Model of Minimum Energy Consumption Ratio Achievable in MANET Using LocationAware Transmission in Ubicomp. ACCN 2016

[20] M. Kaleem GALAMALI, Assoc. Prof Nawaz MOHAMUDALLY, Model of Maximum Energy Consumption Ratio Achievable in MANET Using LocationAware Transmission in Ubicomp. ACCN 2016

[21] M. Kaleem GALAMALI, Assoc. Prof Nawaz MOHAMUDALLY, Model of Overall Energy Consumption Fairness Ratio Achievable in MANET Using LocationAware Transmission in Ubicomp. ACCN 2016

[22] M. Kaleem GALAMALI, Assoc. Prof Nawaz 
MOHAMUDALLY, Model of Overall Energy Consumption Fairness Proportion Achievable in MANET Using LocationAware Transmission for Ubicomp, CEET 2016

[23] M. Kaleem GALAMALI, Assoc. Prof Nawaz MOHAMUDALLY, Model of Minimum Fairness Proportion Achievable in MANET Using Location-Aware Transmission for Ubicomp, CEET 2016

[24] M. Kaleem GALAMALI, Assoc. Prof Nawaz MOHAMUDALLY, Model of Maximum Fairness Proportion Achievable in MANET Using Location-Aware Transmission for Ubicomp, CEET 2016

[25] M. Kaleem GALAMALI, Assoc. Prof Nawaz MOHAMUDALLY, Model of Sender Fairness Proportion Achievable in MANET Using Location-Aware Transmission for Ubicomp, CEET 2016

[26] M. Kaleem GALAMALI, Assoc. Prof Nawaz MOHAMUDALLY, Model of Distance Travelled by packets in MANETs using Location-Aware Transmission for Ubicomp, CEET 2016

[27] M. Kaleem GALAMALI, Assoc. Prof Nawaz MOHAMUDALLY, Model of Maximum CBR Distance Travelled by packets in MANETs using Location-Aware Transmission for Ubicomp, CEET 2016

[28] M. Kaleem GALAMALI, Assoc. Prof Nawaz MOHAMUDALLY, Model of Minimum CBR Distance Travelled by packets in MANETs using Location-Aware Transmission for Ubicomp, CEET 2016

[29] M. Kaleem GALAMALI, Assoc. Prof Nawaz MOHAMUDALLY, Model of Range CBR Distance Experienced by Transmissions in MANETs using LocationAware Transmission for Ubicomp, CEET 2016

[30] M. Kaleem GALAMALI, Assoc. Prof Nawaz MOHAMUDALLY, Trend Analyses of Parameters of Equations for Sender Node Energy Savings Achievable in ubicomp MANETs using Location-Aware Transmission, ACCN 2017.

[31] M. Kaleem GALAMALI, Assoc. Prof Nawaz MOHAMUDALLY, Trend Analyses of Parameters of Equations for Overall Node Energy Savings Achievable in ubicomp MANETs using Location-Aware Transmission, ACCN 2017.

[32] M. Kaleem GALAMALI, Assoc. Prof Nawaz MOHAMUDALLY, Trend Analyses of Parameters of Equations for Sender Node Extra Energy Savings Achievable in MANET against Direct Node-to-Node Location-Aware Transmission, ACCN 2017

[33] M. Kaleem GALAMALI, Assoc. Prof Nawaz MOHAMUDALLY, Trend Analyses of Parameters of Equations for Overall Nodes Extra Energy Savings Achievable in MANET against Direct Node-to-Node Location-Aware Transmission, ACCN 2017.

[34] M. Kaleem GALAMALI, Assoc. Prof Nawaz MOHAMUDALLY, Trend Analyses of Parameters of Equations for Energy Consumption Ratio Achievable in Ubicomp MANET Using Location-Aware Transmission, ACCN 2017.

[35] M. Kaleem GALAMALI, Assoc. Prof Nawaz MOHAMUDALLY, Trend Analyses of Parameters of Equations for Minimum Energy Consumption Ratio Achievable in Ubicomp MANETs Using Location-Aware Transmission, ACCN 2017.

[36] M. Kaleem GALAMALI, Assoc. Prof Nawaz MOHAMUDALLY, Trend Analyses of Parameters of Equations for Maximum Energy Consumption Ratio Achievable in Ubicomp MANETs Using Location-Aware Transmission, ACCN 2017.

[37] M. Kaleem GALAMALI, Assoc. Prof Nawaz MOHAMUDALLY, Trend Analyses of Parameters of Equations for Overall Fairness Ratio Achievable in Ubicomp MANETs Using Location-Aware Transmission, ACCN 2017, CEET 2017

[38] M. Kaleem GALAMALI Assoc Prof Nawaz MOHAMUDALLY, Trend Analyses of Parameters of Equations for Energy Consumption Fairness Proportion Achievable in Ubicomp MANETs Using Location-Aware Transmission, CEET 2017

[39] M. Kaleem GALAMALI, Assoc. Prof Nawaz MOHAMUDALLY, Trend Analyses of Parameters of Equations for Minimum Fairness Proportion Achievable in Ubicomp MANETs Using Location-Aware Transmission,
CEET 2017

[40] M. Kaleem GALAMALI, Assoc. Prof Nawaz MOHAMUDALLY, Trend Analyses of Parameters of Equations for Maximum Fairness Proportion Achievable in Ubicomp MANETs Using Location-Aware Transmission, CEET 2017

[41] M. Kaleem GALAMALI, Assoc. Prof Nawaz MOHAMUDALLY, Trend Analyses of Parameters of Equations for Sender Fairness Proportion Achievable in Ubicomp MANETs Using Location-Aware Transmission, CEET 2017

[42] M. Kaleem GALAMALI, Assoc. Prof Nawaz MOHAMUDALLY, Trend Analyses of Parameters of Equations for Packets Per Distance Achievable in Ubicomp MANETs Using Location-Aware Transmission, CEET 2017

[43] M. Kaleem GALAMALI, Assoc. Prof Nawaz MOHAMUDALLY, Trend Analyses of Parameters of Equations for Maximum CBR Distance Achievable in Ubicomp MANETs Using Location-Aware Transmission, CEET 2017

[44] M. Kaleem GALAMALI, Assoc. Prof Nawaz MOHAMUDALLY, Trend Analyses of Parameters of Equations for Minimum CBR Distance Achievable in Ubicomp MANETs Using Location-Aware Transmission, CEET 2017

[45] M. Kaleem GALAMALI, Assoc. Prof Nawaz MOHAMUDALLY, Trend Analyses of Parameters of Equations for Range CBR Distance Achievable in Ubicomp MANETs Using Location-Aware Transmission, CEET 2017

[46] M. Kaleem GALAMALI, Assoc. Prof Nawaz MOHAMUDALLY, Trend Analyses of Critical Values Obtained for Sender Node Energy Savings Achievable in Ubicomp MANETs Using Location-Aware Transmission, CEET 2017

[47] M. Kaleem GALAMALI, Assoc. Prof Nawaz MOHAMUDALLY, Trend Analyses of Critical Values Obtained for Overall Node Energy Savings Achievable in Ubicomp MANETs Using Location-Aware Transmission, CEET 2017

[48] M. Kaleem GALAMALI, Assoc. Prof Nawaz MOHAMUDALLY, Trend Analyses of Critical Values Obtained for Sender Node Extra Energy Savings Achievable in Ubicomp MANET Against Direct Node-to-Node Location-Aware Transmission, CEET 2017

[49] M. Kaleem GALAMALI, Assoc. Prof Nawaz MOHAMUDALLY, Trend Analyses of Critical Values Obtained for Overall Nodes Extra Energy Savings Achievable in Ubicomp MANET Against Direct Node-toNode Location-Aware Transmission, CEET 2017

[50] M. Kaleem GALAMALI, Assoc. Prof Nawaz MOHAMUDALLY, Trend Analyses of Critical Values Obtained for Energy Consumption Ratio Achievable in Ubicomp MANETs Using Location-Aware Transmission Strategies, CEET 2017

[51] M. Kaleem GALAMALI, Assoc. Prof Nawaz MOHAMUDALLY, Trend Analyses of Critical Values Obtained for Minimum Energy Consumption Ratio Achievable in Ubicomp MANETs Using Location-Aware Transmission Strategies, CEET 2017

[52] M. Kaleem GALAMALI, Assoc. Prof Nawaz MOHAMUDALLY, Trend Analyses of Critical Values Obtained for Maximum Energy Consumption Ratio Achievable in Ubicomp MANETs Using Location-Aware Transmission Strategies, CEET 2017

[53] M. Kaleem GALAMALI, Assoc. Prof Nawaz MOHAMUDALLY, Trend Analyses of Critical Values Obtained for Overall Fairness Ratio Achievable in Ubicomp MANETs Using Location-Aware Transmission Strategies, CEET 2017

[54] M. Kaleem GALAMALI, Assoc. Prof Nawaz MOHAMUDALLY, Trend Analyses of Critical Values Obtained for Energy Consumption Fairness Proportion Achievable in Ubicomp MANETs Using Location-Aware Transmission Strategies, ACCN 2017.

[55] M Kaleem GALAMALI, Assoc Prof Nawaz MOHAMUDALLY, Trend Analyses of Critical Values Obtained for Minimum Fairness Proportion Achievable in Ubicomp MANETs Using Location-Aware Transmission Strategies, ACCN 2017. 
[56] M. Kaleem GALAMALI, Assoc. Prof Nawaz MOHAMUDALLY, Trend Analyses of Critical Values Obtained for Maximum Fairness Proportion Achievable in Ubicomp MANETs Using Location-Aware Transmission Strategies, ACCN 2017.

[57] M. Kaleem GALAMALI, Assoc. Prof Nawaz MOHAMUDALLY, Trend Analyses of Critical Values Obtained for Sender Fairness Proportion Achievable in Ubicomp MANETs Using Location-Aware Transmission Strategies, ACCN 2017.

[58] Markus Bylund and Zary Segall, Towards seamless mobility with personal servers, 2004

[59] Masugi Inoue, Mikio Hasegawa, Nobuo Ryoki and Hiroyuki Morikawa, Context-Based Seamless Network and Application Control, 2004

[60] Xiang Song, Umakishore Ramachandran, MobiGo: A Middleware for Seamless Mobility, College of Computing Georgia Institute of Technology, Atlanta, GA, USA, August 2007

[61] Budzisz, Ferrús, R., Brunstrom A., Grinnemo, K, Fracchia, R., Galante, G., and Casadevall, F. Towards transport-layer mobility: Evolution of SCTP multihoming, March 2008

[62] Paul Dourish \& Genevieve Bell, Divining a digital future, 2011.

[63] Xiang Song, Seamless Mobility In Ubiquitous Computing Environments, PhD Thesis, Georgia Institute of Technology, August 2008

[64] Kevin O Mahony, Jian Liang, Kieran Delaney, User-Centric Personalization and Autonomous Reconfiguration Across Ubiquitous Computing Environments, NIMBUS Centre Cork Institute of Technology, Cork, Ireland, UBICOMM 2012

[65] Pablo Vidales, Seamless mobility in 4G systems, Technical Report, University of Cambridge, Computer Laboratory, Number 656, November 2005

[66] João Pedro Sousa and David Garlan, Aura: An Architectural Framework for User Mobility in Ubiquitous Computing Environments, School of Computer Science, Carnegie Mellon University, USA, August 2002

[67] Dennis Lupiana, Ciaran O'Driscoll, Fredrick Mtenzi, Defining Smart Space in the Context of Ubiquitous Computing, Dublin Institute of Technology, Ireland, Special Issue on ICIT 2009 Conference - Web and Agent Systems, 2009

[68] N.S.V.Shet1, Prof.K.Chandrasekaran2 and Prof. K.C.Shet3, WAP Based Seamless Roaming In Urban Environment with Wise Handoff Technique, International Journal of UbiComp (IJU), Vol.1, No.4, October 2010

[69] Yipeng Yu Dan He Weidong Hua Shijian Li Yu Qi Yueming Wang Gang Pan, FlyingBuddy2: A Braincontrolled Assistant for the Handicapped, Zhejiang University, UbiComp'12, September 5-8, 2012.

[70] Jing Su, James Scott, Pan Hui, Jon Crowcroft, Eyal de Lara Christophe Diot, Ashvin Goel, Meng How Lim, and Eben Upton, Haggle: Seamless Networking for Mobile Applications, 2007

[71] Rui Han, Moustafa M. Ghanem, Li Guo, Yike Guo*, Michelle Osmond, Enabling cost-aware and adaptive elasticity of multi-tier cloud applications, Future Generation Computer Systems, 2012

[72] Byrav Ramamurthy, K. K. Ramakrishnan, Rakesh K. Sinha, Cost and Reliability Considerations in Designing the NextGeneration IP over WDM Backbone Networks, 2012.

[73] Bhavish Aggarwal, Aditya Akella, Ashok Anand, Athula Balachandran, Pushkar Chitnis, Chitra Muthukrishnan, Ram Ramjee and George Varghese, EndRE: An End-System Redundancy Elimination Service for Enterprises, NSDI 2010, San Jose, CA

[74] Ashok Anand, Vyas Sekar and Aditya Akella, SmartRE: An Architecture for Coordinated Network-wide Redundancy Elimination, SIGCOMM 2009, Barcelona, Spain

[75] John Breeden II, "Smart-phone battery life could double without better batteries", Nov 14, 2012

[76] Andy Boxall, "When will your phone battery last as long as your kindle", December 5, 2012.

[77] Imielinski, T. and Navas, J.C. (1999). GPS-based geographic addressing, routing, and resource discovery. Comms. ACM, Vol. 42, No. 4, pp. 86-92

[78] Hightower, J. and Borriello, G. (2001). Location Systems for Ubiquitous Computing. IEEE Computer, Vol. 34, No. 8, August, pp. 57-66.

[79] Harter, A., Hopper, A., Steggles, P., Ward, A. and Webster, P. (2002). The Anatomy of a Context-Aware Application. Wireless Networks, Vol. 8, No. 2-3, Mar-May, pp. 187-197.
[80] Hightower, J., Brumitt, B. and Borriello, G. (2002). The Location Stack: A Layered Model for Location in Ubiquitous Computing. Proceedings of the 4th IEEE Workshop on Mobile Computing Systems \& Applications (WMCSA 2002), Callicoon, NY, USA, June, pp. 22-28.

81] Graumann, D., Lara, W., Hightower, J. and Borriello, G. (2003). Real-world implementation of the Location Stack: The Universal Location Framework. Proceedings of the 5th IEEE Workshop on Mobile Computing Systems \& Applications (WMCSA 2003), Monterey, CA, USA, October pp. 122-128.

[82] Ko, Y., \& Vaidya, N. H. (2000). Location-aided routing (LAR) in mobile ad hoc networks. Wireless Networks, 6(4), 307-321.

[83] Liao, W.-H., Tseng, Y.-C., \& Sheu, J.-P. (2001). GRID: fully location-aware routing protocol for mobile ad hoc networks. Telecommunication Systems, 18(1), 37-60.

[84] Kuhn, F., Wattenhofer, R., Zhang, Y., \& Zollinger, A. (2003). Geometric ad-hoc routing: of theory and practice. In Proceedings of the ACM (PODC'03) (pp. 63-72).

[85] Jiang, X., \& Camp, T. (2002). Review of geocasting protocols for a mobile ad hoc network. In Proceedings of the Grace Hopper Celebration (GHC).

[86] Ko, Y. \& Vaidya, N. H. (1999). Geocasting in mobile ad hoc networks: location-based multicast algorithms. In Proceedings of the IEEE (WMCSA'99) (pp. 101).

[87] Mauve, M., Fuler, H., Widmer, J., \& Lang, T. (2003). Position-based multicast routing for mobile ad-hoc networks (Technical Report TR-03-004). Department of Computer Science, University of Mannheim.

[88] Xu, Y., Heidemann, J., \& Estrin, D. (2001). Geographyinformed energy conservation for adhoc routing. In Proceedings of the ACM/IEEE (MOBICOM'01) (pp. 70-84).

[89] Hu, Y.-C., Perrig, A., \& Johnson, D. (2003). Packet leashes: a defense against wormhole attacks in wireless ad hoc networks. In Proceedings of the INFOCOM' 03 (pp. 1976-1986).

[90] Patwari, N., Hero III, A. O., Perkins, M., Correal, N. S., \& O'Dea, R. J. (2003). Relative location estimation in wireles sensor networks. IEEE Transactions on Signal Processing, 51(8), 2137-2148

[91] Baldauf, M., Dustdar, S., \& Rosenberg, F. (2007). A Survey on Context Aware Systems. International Journal of Ad Hoc and Ubiquitous Computing, Inderscience Publishers. forthcoming. Pre-print from: http://www.vitalab.tuwien.ac.at/ florian/papers/ijahuc2007.pdf

92] Hong, D., Chiu, D.K.W., \& Shen, V.Y. (2005). Requirements elicitation for the design of context-aware applications in a ubiquitous environment. In Proceedings of ICEC'05 (pp. 590-596).

[93] Neeraj Tantubay, Dinesh Ratan Gautam and Mukesh Kumar Dhariwal, A Review of Power Conservation in Wireless Mobile Ad hoc Network (MANET)", International Journal of computer Science Issues, Vol 8, Issue 4, No 1, July 2011

[94] Wenrui Zhao, Mostafa Ammar and Ellen Zegura, "A Message Ferrying Approach for Data Delivery in Sparse Mobile Ad Hoc Networks", MobiHoc'04, May 24-26, 2004, Roppongi, Japan.

[95] Sgroi et al., "Designing Wireless Protocols: Methodology and Applications, February 2000.

[96] Gyula et al., "Simulation-based optimization of communication protocols for large-scale wireless sensor networks", 10 October 2002

[97] Rao and Sharma, "Cross Layer Protocols For Multimedia Transmission in Wireless Networks", June 2012

About Author (s):

Associate Professor Nawaz Mohamudally works at University of Technology, Mauritius (UTM) and has undertaken supervision of MPhil/PhD Students for many years.

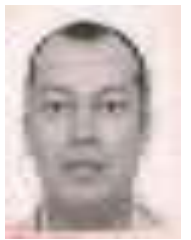

M. Kaleem Galamali is a part-time student (achieved M Phil Transfer on 28.10.2014, currently $\mathrm{PhD}$ student) at UTM under supervision of A.P. Nawaz Mohamudally. 